\title{
Feasibility of biogas as a green energy source in the central part of South Sulawesi
}

\author{
Abbas $^{1 *}$, Ayusari Wahyuni ${ }^{2}$, Nurul Fuadi ${ }^{2}$, A. Muhammad Syafar ${ }^{3}$ \\ ${ }^{1}$ Animal Science Department, Faculty of Science and Technology UIN Alauddin Makassar \\ ${ }^{2}$ Physics Department, Faculty of Science and Technology UIN Alauddin Makassar \\ ${ }^{3}$ Informatics Engineering Department, Faculty of Science and Technology UIN Alauddin Makassar
}

\begin{abstract}
The goal of this work is the feasibility of biogas as a green energy source produced from organic matter from ruminants, equine and farming activities in the central part of South Sulawesi. The study was conducted with survey and laboratory analysis to calculate the number of ruminants, corn, and rice stalk using supporting data from the South Sulawesi Statistics office. Amounts of 84,567, 112,915, and 3,579 ruminants have been raised in Maros, Gowa, and Makassar, respectively. While 6,757, 9,529, and 50 monogastric are raised in Maros, Gowa, and Makassar. Corn and rice stalks were produced $465,878.06$ tons year-1 in Gowa and Maros. Every cattle and equine can produce feces up to $25 \mathrm{~kg}$ day $^{-1}$ and $30 \mathrm{~kg} \mathrm{day}^{-1}$, daily feces production equals $2,316,885 ; 3,108,745$; and $90,975 \mathrm{~kg} \mathrm{day}^{-1}$ in Maros, Gowa, and Makassar, respectively. These waste products can be converted to biogas as source of green energy with a total yield of $667,752,675,489.20 \times 103 \mathrm{cc}$. Its production ratio is $1 \mathrm{~kg}$ dry matter: 1,051.3-liter biogas for beef feces and $1 \mathrm{~kg}$ dry matter: 3,980-liter biogas for equine feces and corn and rice stalks can be applied as organic fertilizer as a significant factor in anaerobic fermentation of biogas production.
\end{abstract}

\section{Introduction}

As European Commission has launched a "The green new deal", this set of policy has inspired many countries globally to deal with climate change and set a climate neutral target by 2050 [1-2], many Asian countries such as Indonesia as well as has set similar target. This in line with The Intergovernmental Panel on Climate Change (IPCC) which suggest that by 2050 up to $77 \%$ of energy utilization has to be supplied from green energy [3]. Indonesia is one of Asian countries in the world which has to reduce greenhouse gas (GHG) production and its impact in a bid to neutralize global warming impact. Considering the fact that Indonesia has huge number of agricultural activities which has negative ramification both on atmosphere and climate [4]

\footnotetext{
* Corresponding author: adolf_scfm@yahoo.co.uk
} 
Residues from agricultural activities such as corn stalk and rice stalk and feces from animals have huge potential green energy resources [5]. A special measure is in fact needed to tackle this problem whether a certain regulation or engagement of communities [6].

Less-utilized animal manure and corn and rice stalks which are produced annually are common in developing countries [7], corn and rice stalk mostly given to cattle as daily feeding [8]. Hence animal manure as well as corn and rice stalk has huge potential as raw material of biogas production as a green energy source due its abundance of cellulose ingredient [9]. It is feasible in the near future to rely on green energy sources such as biogas for supplying the energy demand which is generated from organic matter as for now it is estimated around $80 \%$ energy consumption generated from fuel [10].

Thus, the objective of this work was aimed to approximate the potential of biogas production from both of animal manure such as ruminant (cattle) as well as monogastric (equine) and other organic matter such as corn and rice stalk in three parts of South Sulawesi Indonesia.

This study also intends to investigate the alternative green energy resource, which is biogas in further detail for those three areas in the central part of South Sulawesi. As an effort to identify hot-spot sites which produced methane $\left(\mathrm{CH}_{4}\right)$ we combined our previous study with data from local government body and various studies across the world [11].

\subsection{Study area}

This study was conducted in the central part of South Sulawesi which consists of three regencies and city namely; Maros regency, Gowa regency and Makassar city. These sites are the most populated area in South Sulawesi and mostly they have committed farming practices [16].

\section{Methodology}

\subsection{Data collection}

Livestock herding as well as corn and rice stalk production in 2020 for three sites in central part of South Sulawesi (Maros regency, Gowa regency and Makassar city) have been collected from Bureau of Statistical Center in each local government body. Chart in the text was drawn by using ArcGIS10.2 Software.

\subsection{Laboratory analysis}

Approximation regarding raw material exertion was implemented on a dry matter basis. Dry matter content of animal manure and other properties were determined by Kjeldahl method and methane $\left(\mathrm{CH}_{4}\right)$ concentration was measured by gas chromatography, while methane $\left(\mathrm{CH}_{4}\right)$ production was calculated by equation as follows [11];

$$
\mathrm{MP}=\mathrm{Y} / 100 \times \mathrm{Z}
$$

where MP; methane $(\mathrm{CH} 4)$ production, $(\mathrm{ml} / 100 \mathrm{~g} \mathrm{DM}) \mathrm{Y}$; methane $\left(\mathrm{CH}_{4}\right)$ concentration $(\%)$ and $\mathrm{Z}$; whole gas production (1). For biogas production both feces were scaled then mixed with water to reach optimum ratio $(9-11 \%)$ of dry matter in anaerobic fermentation for 30 days retention and biogas production was measured for daily basis. 
In addition, for comparison purposes in calculation of biogas potential in three areas in central parts of South Sulawesi this study uses corn and stalk properties and yields biogas production data from previous studies that were conducted in similar climates.

\section{Results}

Cattle and equine population which have been raised in three areas are presented in fig.1. While animal manure and corn and rice stalk properties are depicted in Table 1. In addition, theoretical biogas potential from animal manure and corn and rice stalk in central part of South Sulawesi has been projected in Table 2.

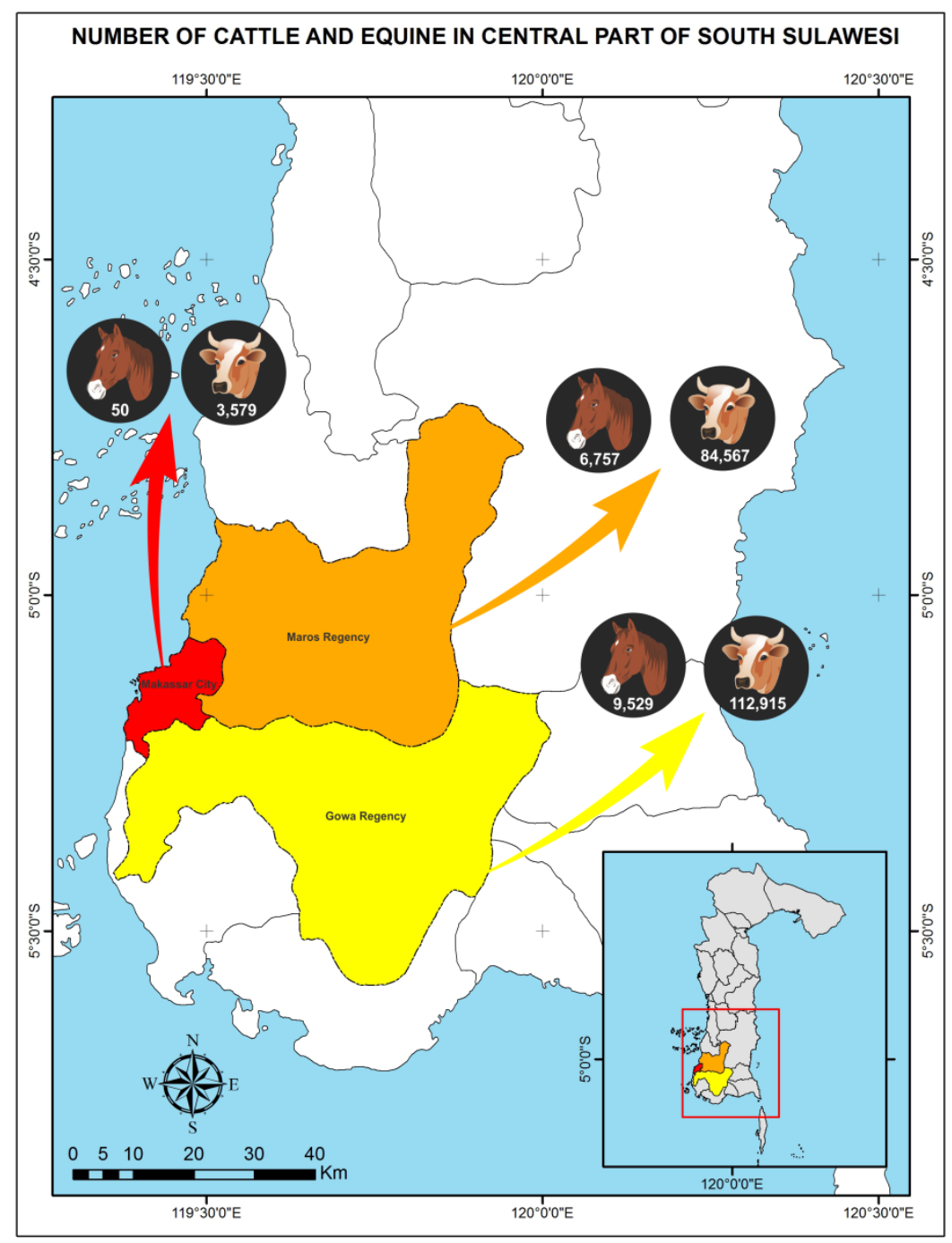

Fig. 1. Population of cattle and equine in three sites in central South Sulawesi 
Table 1. Animal manure and corn and rice stalk properties measured in percent (\%)

\begin{tabular}{|l|l|l|r|l|}
\hline \multirow{2}{*}{ Properties } & \multicolumn{2}{|c|}{ Animal manure } & \multicolumn{2}{c|}{ Stalk* $^{*}$} \\
\cline { 2 - 5 } & Cattle & Equine & Corn & Rice \\
\hline Dry matter & 22.83 & 28.73 & 8.94 & 22.25 \\
\hline Moisture & 77.17 & 71.27 & 91.06 & 77.75 \\
\hline c/n ratio & 18.30 & 25.10 & 40.90 & 51.11 \\
\hline Crude protein & 6.35 & 4.39 & 5.80 & 8.26 \\
\hline Crude fiber & 32.72 & 41.04 & 27.38 & 31.99 \\
\hline
\end{tabular}

*Source: $[12,13,14,15]$

Table 2. Theoretical biogas potential from animal manure and corn and rice stalk in central part of South Sulawesi

\begin{tabular}{|l|r|c|c|c|}
\hline \multirow{2}{*}{ Region } & \multicolumn{3}{|c|}{ Annual production $\left(\mathbf{x 1 0}^{\mathbf{3}} \mathbf{k g}\right) *$} & $\begin{array}{c}\text { Biogas yield } \\
\text { approximation } \\
\left.\mathbf{( 1 0}^{\mathbf{3}} \mathbf{c c}\right)\end{array}$ \\
\cline { 2 - 4 } & Cattle & Equine & Corn and rice stalk $^{*}$ & $8,463,774,376$ \\
\hline Makassar city & 32,658 & 547 & - & $366,606,185,082.71$ \\
\hline Gowa regency & $1,030,349$ & 104,342 & 261,541 & $292,682,716,030.67$ \\
\hline Maros regency & 771,673 & 73,989 & 204,337 & $667,752,675,489.20$ \\
\hline Total & $1,834,680$ & 178,878 & 465,878 & \\
\hline
\end{tabular}

* Source: [16]

\subsection{Animal populations}

Cattle and equine are raised in open yards where they feed themselves and secrete their feces in pasture on top of grass or soil. These animal populations are raised mostly for side income for the farmer so that they let them graze without any consideration of environmental impact from their cattle [16].

\subsection{Biogas production}

Biogas production has occurred since the first week of the fermentation process. However, methane $\left(\mathrm{CH}_{4}\right)$ composition which was generated in this phase is low. This lack of methane $\left(\mathrm{CH}_{4}\right)$ gas situation was due to domination of $\mathrm{CO}_{2}$ gas up to the $14^{\text {th }}$ day which leads to impurity of biogas that generates low energy in the combustion process.

The total volume of biogas production per $1000 \mathrm{~g}$ DM during the recent time of fermentation process was taken to account for green energy approximation with $1.051,3 \mathrm{x}$ $10^{3} \mathrm{cc}$ for cattle feces and $3.980 \times 10^{3} \mathrm{cc}$ for equine feces. Thus, estimation of total biogas production from both feces $667,752,675,489.20 \times 10^{3} \mathrm{cc}$.

These figures are equal to around 417,345,422.2 liters of kerosene which could supply energy for 2,006,468 families for cooking purposes on the sites during the year [17]. Assuming mostly every family has up to 2 children. It could have very significant impact for the environment in spite of letting them freely emitted to the atmosphere as greenhouse gas. Biogas as a green energy source could provide several solutions on waste management, organic matter recycling, renewable energy and agricultural sustainability [18]. Certain change both in the technology and the properties of organic matters could influence of the result of biogas approximations. [19] 


\subsection{Methane $\left(\mathrm{CH}_{4}\right)$ emission}

Methane $\left(\mathrm{CH}_{4}\right)$ which is emitted from cattle and equine feces as well as from corn and rice stalk in the three sites is abundant and brings a huge impact on the atmosphere. Their huge accumulation leads to global warming and climate change. In all cases, methane $\left(\mathrm{CH}_{4}\right)$ emission mainly comes from field spreading of manure and stalks which has biogenic origin [20]. Furthermore, spreading animal manure and other organic matter could lead to deteriorating atmosphere conditions due to emission of ammonia and nitrate [21].

\section{Discussion}

This study approximates the possibility of a huge amount of green energy source such as biogas in the central part of South Sulawesi which is possible to be converted from various organic matters such as animal manure as well as corn and rice stalk. It has also been assessed the possibility of greenhouse gas production and its impact on the atmosphere around this area.

It is common knowledge that Makassar city and some other regency near it are vulnerable to more exposure to extreme heat considering that most of these site's latitude 0 - 10 meters above sea level. Furthermore, constant production of methane $\left(\mathrm{CH}_{4}\right)$ as a greenhouse gas is deteriorating this condition [16].

However, collecting and applying those gas accumulations from ruminant (cattle) and monogastric (equine) will be able to reduce the negative impact on the atmosphere of those areas. Furthermore, deploying organic matter from farming practices such as corn and rice stalk could enhance biogas production in anaerobic fermentation considering that those stalks have high $\mathrm{C} / \mathrm{N}$ ratio that play a key role on generating methane $\left(\mathrm{CH}_{4}\right)$ inside of anaerobic digester [22].

Our finding is also indicating that the central part of South Sulawesi has huge green energy potential from animal manure and organic waste from corn and rice stalk. It might be noted that our approximation of biogas feasibility as green energy in three areas in the central part of South Sulawesi as well as its impact on the atmosphere of these sites could be significant information for reducing global warming impact and climate change in one of Indonesia's provinces. Although uncertainty is associated with the approximation, this study could assist to establish a model or projection about how the atmosphere will be affected in the several years to come as well as to build biogas plants in certain areas to capitalize green energy potential as alternative source energy that is environmentally friendly.

\section{Conclusion}

Huge potential amount of biogas production with total yield could reach $667,752,675,489.20 \times 10^{3} \mathrm{cc}$ is significant figure in terms of impact on climate change. Attempting to reduce climate change for environmental sustainability is crucial and inevitable. Committing this measure and deploying biogas plants not only keeps at bay the increase of surface temperature but also provides alternative green energy sources for local people in three populated areas in the central part of South Sulawesi. The biogas generation for both electricity and transportation could play a key role of reducing greenhouse gas emission, and enhancing green energy consumption which is produced from animal manure as well as corn and rice stalk. However, this huge potential needs such special measurement from Indonesian government to support the implementation of applying green energy resources as the main contributor for energy demand and deploying biogas plants across the whole of the country. 


\section{References}

1. European Commission, The European Green Deal https://eur-lex.europa.eu/ resource.html? uri $1 / 4$ cellar:b828d165-1c22-11 ea-8c1f-01aa75ed71a1.0002.02/DOC_1\& amp. (2019) (Accessed 30 November 2020)

2. C. Beausang, K. McDonnell, F. Murphy, J. Cleaner Prod. 298 (2021)

3. S. Croce, Q.Wei, D.G. Imporzano, R. Dong, F. Adani. Biotech. Adv. J. 09 (2016)

4. E.Saptutyningsih, D. Diswandi, W. Jaung, Land Use Policy. 95, 104189 (2020)

5. W.Zhong, Z.Zhang, Y. Luo, S. Sun, W. Qiao, M. Xiao, J. Bioresource Techn. 102 (2011)

6. F. Mulyasari, A.K. Harahap, A.O.Rio, R.Sule, W.G.A.Kadir. International J. of Greenhouse Gas Control. 108 (2021)

7. A. Demirbas, Energ. Convers. Manage. 42 (2001)

8. B. H. Hameed, M.I. EI-Khaiary. J. Hazard.Mater. 153 (2008)

9. D. Xua, Z. Ding, J. Bai, W. Kea, Y. Zhang, F. Li, X. Guo. Bioresource Technology. $310(2020)$

10. D.M. Yazan, F. Fraccascia, M. Mes, H. Zijm, Applied Energy. 212, 820-833 (2018)

11. S. Abbas, Triatmojo, L.M.Yusiati, Bul. Peternakan. 36, 2 (2012)

12. N. Suningsih, W. Ibrahim, O. Liandris, R. Yulianti, Jurnal Sain Peternakan Indonesia, (2019)

13. Sismiyanti, Hermansah, Yulnafatmawita, J. Solum. 15, 1 (2018)

14. N. Annisa, Wiyoto, J. Pusat Inovasi Masyarakat. 1 (2019)

15. S. Bahar, Bul. Pertanian Perkotaan. 6, 2 (2016)

16. BPS-Statistics of Sulawesi Selatan Province, Sulawesi Selatan in Figures 2020 (BPS Sulawesi Selatan, 2020)

17. Energypedia, Bleens - Biogas, Liquefied Petroleum Gas, Electricity, Ethanol, Natural Gas, and Solar, https://energypedia.info/wiki/BLEENS - Biogas, Liquefied Petroleum_Gas,_Electricity,_Ethanol,_Natural_Gas,_and_Solar, accessed on 11 June (2021)

18. B. Beausang, K. McDonnell, F. Murphy. Journal of Cleaner Production. 298 (2021)

19. V. Burg, K.G. Troitzsch, D. Akyol, U. Baier, S. Hellweg, O. Thees. Resources, Conservation \& Recycling. 167 (2021)

20. U. Kreidenweis, J. Breier, C. Herrmann, J. Libra, A. Prochnow. J. of Cleaner Production. 280 (2021)

21. F. Valentinuzzi, L. Cavani, C. Porfido, R. Terzano, Y. Pii, S. Cesco, C. T. Marzadori, Heliyon. 6 (2020)

22. T. Soha, L. Papp, C. Csontos, B. Munkacsy. Renewable and Sustainable Energy Reviews. 141 (2021) 